\title{
Bacteriological Examination of Computer Keyboards and Mouse Devices and Their Susceptibility Patterns to Disinfectants
}

\author{
${ }^{1}$ Onochie Charles Chimezie, ${ }^{2}$ Anyim Chukwudi, ${ }^{3}$ Alo Moses Nnaemeka, \\ ${ }^{2}$ Onwa Ndubuisi Collins, ${ }^{2}$ Okonkwo Eucharia Chinyere and ${ }^{2}$ Afiukwa Felicitas Ngozi \\ 'Department of Applied Microbiology and Brewing, \\ Faculty of Biosciences, Nnamdi Azikiwe University Awka, Anambra State, Nigeria \\ ${ }^{2}$ Department of Applied Microbiology, Faculty of Biological Sicences, Ebonyi State University, Abakaliki, Nigeria \\ ${ }^{3}$ Department of Biological Sciences, \\ Faculty of Science and Technology, Federal University Ndufu Alike-Ikwo, Ebonyi State, Nigeria
}

Received 2013-01-26, Revised 2013-03-19; Accepted 2013-01-19

\begin{abstract}
Computers are ubiquitous and have been shown to be contaminated with potentially pathogenic bacteria in some communities. There is no economical way to test all the keyboards and mouse out there, but there are common-sense ways to prevent bacterial contamination or eliminate it if it exists. In this study, swabs specimens were collected from surfaces of 250 computer keyboards and mouse and plated on different bacteriological media. Organisms growing on the media were purified and identified using microbiological standards. It was found that all the tested computer keyboards and mouse devices, were positive for microbial contamination. The percentages of isolated bacteria (Staphylococcus spp., Escherichia spp., Pseudomonas spp. and Bacillus spp.) were 43.3, 40.9, 30.7, 34.1, 18.3, 18.2, 7.7 and 6.8\% for computer keyboards and mouse respectively. The isolated bacteria were tested against the 6 different disinfectants (Dettol, Isol, Izal, JIK, Purit and Septol ${ }^{\circledR}$ ). Antibacterial effects of the disinfectants were also concentration dependent. The agar well diffusion technique for determining Minimum Inhibitory Concentration (MIC) was employed. The Killing rate (K) and Decimal Reduction Time (DRT) of the disinfectants on the organism were also determined. The overall result of this study showed that Dettol ${ }^{\circledR}$, followed by JIK $^{\circledR}$ was highly effective against all the bacterial isolates tested while Septol and Izal ${ }^{\circledR}$ were least effective. Isol and Purit $^{\mathbb{R}}$ showed moderate antibacterial effects. Keyboards and mouse should be disinfected daily. However, it is recommended that heightened surveillance of the microbial examination of computer keyboards should be undertaken at predetermined intervals.
\end{abstract}

Keywords: Bacteria, Computer, Disinfectants, Antibacterial Activity, MIC, DRT, Killing Rate

\section{INTRODUCTION}

Computer is an electronic data processing machine which accepts data from the out-side world inform of an input and manipulates, calculates, computes on the basis of set of instructions supplied and stored in the memory and give the required or desired results in the form of an output to the user (Ravichandran, 2001).
Because of frequent-dermal contact by numerous users, microbial reservoirs of interest includes the computer keyboard and mouse (Neely et al., 2005a; Wilson et al., 2006). Anderson and Palambo (2009) documented that the average number of microorganisms present on multiple-user computer keyboards was significantly greater than on singleuser keyboards.

Corresponding Author: Onochie Charles Chimezie, Department of Applied Microbiology and Brewing, Faculty of Biosciences, Nnamdi Azikiwe University Awka, Anambra State, Nigeria 
Computer hardware has been implicated as a potential reservoir for infectious agents (Neely et al., $2005 \mathrm{~b}$ ). Of increasing concern, however, is the role of keyboards in the non-hospital environment as pathogen reservoirs (Eguia and Chamber, 2003). It follows that the ubiquitous sharing of public computers by a broad user base might facilitate increased transmission and prevalence of pathogenic microorganisms throughout the community (Eltablawy and Elhifnawi, 2009). Inadequately performed hand hygiene and nondisinfected surfaces are two reasons why the keys and mouse-buttons of laptops could be sources of microbial contamination resulting consequently in indirect transmission of potential pathogens and nosocomial infections (Siegmund et al., 2010).

Surprisingly, little effort has been dedicated to identify the role of inanimate surfaces as pathogen reservoirs in the non-hospital settings (Pancholi et al., 2005; Stepanovic et al., 2008). Therefore, successive steps to edge the spread of antimicrobial resistant pathogens throughout the community should include efforts to not only increase awareness of appropriate hygiene and decontamination strategies, but also to reveal the ecology of bacteria contaminating community surfaces.

This study was undertaken to evaluate the bacteriological examination of computer keyboards and mouse devices and their susceptibility patterns to commonly used disinfectants.

\section{MATERIALS AND METHODS}

\subsection{Study Area}

This study was conducted within three campuses (Presco, CAS and Ishieke) of the Ebonyi State University, Abakaliki.

\subsection{Ethical Clearance}

The consent and permission of the cyber cafes owners were inquired in order to carry out this research work. Subsequently, the confidentiality of the information obtained from cyber cafes was kept.

\subsection{Sample Collection and Preparation}

The surfaces of 250 computer keyboards and mouse of 15 cyber cafes in three campuses (Presco, CAS and Ishieke) were randomly selected for this study. This was performed during operating hours featuring normal students and staff traffic at the cyber cafes. The single sterile swab stick moistened with sterile saline solution were moved over the surfaces being tested (keyboard and mouse). The swab sticks were immediately transported to the laboratory.

\subsection{Collection of Disinfectants}

The following disinfectants: Dettol ${ }^{\circledR} \quad$ (Reckitt Benkiser Ltd, Nigeria), Isol ${ }^{\circledR}$ (Medreich Ltd, Nigeria), Izal $^{\circledR}$ (Medreich Ltd, Nigeria), JIK ${ }^{\circledR}$ (Reckitt Benkiser Ltd, Nigeria), Purit ${ }^{\circledR}$ (Saro Lifecare Ltd, Nigeria) and Septol $^{\circledR}$ (Gongoni Company Ltd, Nigeria) commonly used in Abakaliki Metropolis were obtained from Ceno Pharmacy, Abakaliki, Ebonyi State.

\subsection{Identification of the Isolates}

Identification of the test isolates was done based on morphological and biochemical test: Sugar fermentation test (glucose, fructose and lactose), Voges Proskauer test, catalase test, coagulase test, oxidase test and indole test, including Gram staining reaction and motility test was carried out for proper characterization of bacterial isolates according to Cheesbrough (2006).

\subsection{Dilution of Disinfectant}

Serial dilution method was used to dilute the disinfectants into 50, 25 and $12.5 \%$ concentration according to Awodele et al. (2007).

\subsection{Standardization of Test Organisms}

The isolates used for sensitivity were standardized using the $0.5 \mathrm{McF}$ arland equivalent standard as described by Cheesbrough (2006).

\subsection{Susceptibility Testing}

The susceptibility testing of the commonly used disinfectants were ascertained using agar well diffusion method (Awodele et al., 2007; Iroha et al., 2011).

\section{RESULTS}

The organisms were then characterized as shown in Table 1. Four bacteria were isolated in this study and suspected to contaminate computer keyboards and mouse.

Out of 250 samples analyzed, a total of 148 bacteria isolates were isolated from computer keyboards and mouse. Out of which 63 Staphylococcus spp. were present; 45 of the isolates were from keyboards and 18 from mouse. 11 were Bacillus spp.; 8 of the isolates from keyboards and 3 from mouse. 47 were Escherichia spp.; 32 of the isolates from keyboards and 15 from mouse. 27 were Pseudomonas spp.; 19 of the isolates from keyboards and 8 from mouse. A total of 104 bacterial isolates were obtained from keyboards and 44 bacterial isolates from mouse (Table 2). 
Onochie Charles Chimezie et al. / American Journal of Microbiology 4 (1): 9-19, 2013

Table 1. Morphological and biochemical test result of bacterial isolated from computer keyboards and mouse

\begin{tabular}{|c|c|c|c|c|c|c|c|c|c|c|c|}
\hline \multicolumn{2}{|c|}{ Morphological characterization } & \multicolumn{10}{|c|}{ Sugar fermentation test } \\
\hline Colour & $\begin{array}{l}\text { Consistency/ } \\
\text { texture }\end{array}$ & $\begin{array}{l}\text { Gram } \\
\text { staining }\end{array}$ & $\begin{array}{l}\text { Catalase } \\
\text { test }\end{array}$ & $\begin{array}{l}\text { Oxidase } \\
\text { test }\end{array}$ & $\begin{array}{l}\text { Indole } \\
\text { test }\end{array}$ & $\begin{array}{l}\text { Voges } \\
\text { proskauer }\end{array}$ & $\begin{array}{l}\text { Motility } \\
\text { test }\end{array}$ & Glucose & Lactose & Fructose & $\begin{array}{l}\text { Suspected } \\
\text { organisms }\end{array}$ \\
\hline Creamy & $\begin{array}{l}\text { Raised/smooth } \\
\text { edge }\end{array}$ & + ve & + & - & - & - & - & + & - & - & $\begin{array}{l}\text { Staphylococcus } \\
\text { spp. }\end{array}$ \\
\hline Grayish & Small round colony & $+\mathrm{ve}$ & - & + & - & - & - & + & - & - & Bacillus spp. \\
\hline Greenish & Rough surface & -ve & + & - & + & - & - & + & + & - & Escherichia spp. \\
\hline Light yellow & Slightly raised & $-\mathrm{ve}$ & + & + & - & - & - & + & - & - & Pseudomonas spp. \\
\hline
\end{tabular}

Table 2. Frequency of bacterial occurrence in computer keyboards and mouse

\begin{tabular}{|c|c|c|c|}
\hline Isolates & Keyboards (\%) & Mouse $(\%)$ & Total No. (\%) \\
\hline Staphylococcus spp. & $45(43.3)$ & $18(40.9)$ & $63(42.6)$ \\
\hline Bacillus spp. & $8(7.7)$ & $3(6.8)$ & $11(7.4)$ \\
\hline Escherichia spp. & $32(30.7)$ & $15(34.1)$ & $47(31.8)$ \\
\hline Pseudomonas spp. & $19(18.3)$ & $8(18.2)$ & $27(18.2)$ \\
\hline Total & 104 & 44 & 148 \\
\hline
\end{tabular}

Table 3. Antimicrobial activities of disinfectants against organisms at 100, 50, 25 and $12.5 \%$ concentration and inhibition zone diameter ( $\mathrm{mm})$

\begin{tabular}{|c|c|c|c|c|c|c|c|c|c|c|c|c|c|c|c|c|}
\hline \multirow[b]{2}{*}{ Disinfectants } & \multicolumn{4}{|c|}{ Staphylococcus spp. } & \multicolumn{4}{|c|}{ Bacillus spp. } & \multicolumn{4}{|c|}{ Escherichia spp. } & \multicolumn{4}{|c|}{ Pseudomonas spp. } \\
\hline & 100 & 50 & 25 & 12.5 & 100 & 50 & 25 & 12.5 & 100 & 50 & 25 & 12.5 & 100 & 50 & 25 & 12.5 \\
\hline Dettol $^{\circledR}$ & 15 & 12 & 10 & 10 & 14 & 10 & 14 & 8 & 15 & 13 & 10 & 12 & 14 & 10 & 12 & 8 \\
\hline Isol $^{\circledR}$ & 12 & 10 & 7 & 4 & 10 & 11 & 5 & - & 11 & 8 & - & - & 10 & 8 & 5 & - \\
\hline $\mathrm{Izal}^{\circledR}$ & 8 & - & - & - & 12 & 4 & - & - & 10 & 5 & - & - & 5 & - & - & - \\
\hline $\mathrm{JIK}^{\circledR}$ & 13 & 12 & 10 & 8 & 13 & 12 & 11 & 5 & 12 & 5 & 8 & 5 & 10 & 11 & 9 & 7 \\
\hline Purit $^{\circledR}$ & 10 & 8 & 5 & - & 9 & - & 5 & - & 5 & - & 4 & - & 7 & 4 & - & - \\
\hline Septol $^{\circledR}$ & 5 & - & - & - & 9 & 6 & - & - & - & - & - & - & 10 & 5 & - & - \\
\hline
\end{tabular}

$\underline{\text { Table 4. Minimum inhibitory concentration of disinfectants against test bacteria }}$

\begin{tabular}{|c|c|c|c|c|c|c|}
\hline \multirow[b]{2}{*}{ Strain Name } & \multicolumn{6}{|c|}{$\mathrm{MIC}(\mathrm{mL} / \mathrm{mL})$} \\
\hline & Dettol $^{\circledR}$ & Isol $^{\circledR}$ & Izal $^{\circledR}$ & $\mathrm{JIK}^{\circledR}$ & Purit $^{\circledR}$ & Septol $^{\mathbb{B}}$ \\
\hline Staphylococcus spp. & 4.5731 & 3.5375 & 4.9556 & 3.4498 & 1.0273 & 3.5156 \\
\hline Bacillus spp. & 1.5093 & 2.1468 & 1.9063 & 3.7273 & 1.9629 & 2.5182 \\
\hline Escherichia spp. & 8.4431 & 7.7875 & 4.6249 & 4.2433 & 2.0659 & 3.5116 \\
\hline Pseudomonas spp. & 1.7824 & 2.1468 & 6.3081 & 5.5326 & 6.6711 & 6.1816 \\
\hline
\end{tabular}

At $100 \%$ concentration, Dettol ${ }^{\circledR}$ and $\mathrm{JIK}^{\circledR}$ were the most effective in inhibiting the four organism tested, followed by Isol $^{\circledR}$, while Septol ${ }^{\circledR}$, showed the lowest inhibitory activity on all the organisms at $100 \%$ concentration (Table 3).

However, at 50\% concentration Dettol and $\mathrm{JIK}^{\circledR}$ were also the most effective in inhibitory activities, followed by Isol $^{\circledR}$ on the four organism tested. Izal ${ }^{\circledR}$ showed no inhibitory activity on Staphylococcus and Pseudomonas spp., but showed inhibitory activities on Bacillus and Escherichia spp.. In the same vein, Purit ${ }^{\circledR}$ showed inhibitory activities on Staphylococcus and Pseudomonas spp., but had no inhibitory effect on Bacillus and
Escherichia spp. At this $50 \%$ concentration, Septol ${ }^{\circledR}$ showed inhibitory activities on Bacillus spp. and Pseudomonas spp., but disclosed no inhibitory effect on Staphylococcus and Escherichia spp Table 4.

Furthermore, at $25 \%$ concentration it was revealed that Dettol and JIK $^{\circledR}$ showed reasonable inhibitory activities on Staphylococcus, Bacillus, Escherichia and Pseudomonas spp. followed by Isol $^{\circledR}$ on Staphylococcus, Bacillus and Pseudomonas spp. respectively and showed no inhibitory activity on Escherichia species. Purit ${ }^{\circledR}$ showed inhibitory activities on Staphylococcus, Bacillus and Escherichia spp., but had no inhibitory activity on Pseudomonas spp. Izal 
and Septol ${ }^{\circledR}$ did not show any inhibitory activity at this $25 \%$ concentration to the entire organisms tested.

Finally, at $12.5 \%$ concentration, Dettol and $\mathrm{JIK}^{\circledR}$ demonstrated inhibitory activities on Staphylococcus, Bacillus, Escherichia and Pseudomonas spp. Isol ${ }^{\circledR}$ showed inhibitory activity on only Staphylococcus spp. and had no inhibitory effect on the other organisms. At same 25\% concentration, Purit, Izal and Septol ${ }^{\circledR}$ revealed no inhibitory effects on the other organisms tested.

The killing rates $(\mathrm{K})$ of the organisms obtained from the graphs are given in Table 5. The higher the value of $\mathrm{k}$, the faster the efficiency of the killing process. The killing rates of Staphylococcus spp. by Dettol ${ }^{\circledR}$ were higher than for other disinfectants. Thus, the killing rates $(\mathrm{K})$ of Staphylococcus spp. were -0.044, -0.048, 0.052, -0.058, -0.086 and -0.058 for Dettol, JIK, Isol, Purit, Izal and Septol ${ }^{\circledR}$ respectively. The killing rates (K) of Bacillus spp. were -0.046, -0.050, -0.055, -0.050, -0.061 and 0.055 in Dettol, JIK, Isol, Purit, Izal and Septol $^{\circledR}$ respectively. The killing rates of the other 2 organisms (Escherichia spp. and Pseudomonas spp.) followed a similar pattern.
Table 6 and 7 showed the slopes and the Decimal Reduction Times (DRT) respectively. The DRT is known to be the time required for $90 \%$ reduction in the number of viable cells (Meynell and Meynell, 1970). The DRT for Staphylococcus spp. were 30.30, 33.33, 35.71, 40.00, 58.82 and $40.00 \mathrm{~min}$ in Dettol, JIK, Isol, Purit, Izal and Septol ${ }^{\circledR}$ respectively, while for Bacillus spp. were $32.29,34.48,38.46,34.48,41.67$ and $25.64 \mathrm{~min}$ in Dettol, JIK, Isol, Purit, Izal and Septol ${ }^{\circledR}$ respectively. A similar pattern was recorded for the other 2 organisms (Escherichia spp. and Pseudomonas spp.).

The higher the value of killing rate $(\mathrm{K})$, the lower the value of Decimal Reduction Time (DRT).

Colony counting technique was used to determine the number of colony that survived the effects of various dilutions of each disinfectants and the data plotted as $\log _{10} \mathrm{~N} / \mathrm{N}$ oversus time as in Fig. 1 (Staphylococcus spp.), Fig. 2 (Bacillus species), Fig. 3 (Escherichia spp.) and Fig. 4 (Pseudomonas spp.). For all the organisms there was an overall similarity in the shapes of the curves. The curves initially showed a lag, the duration of which depended on the concentration of the disinfectant and the type of organism.

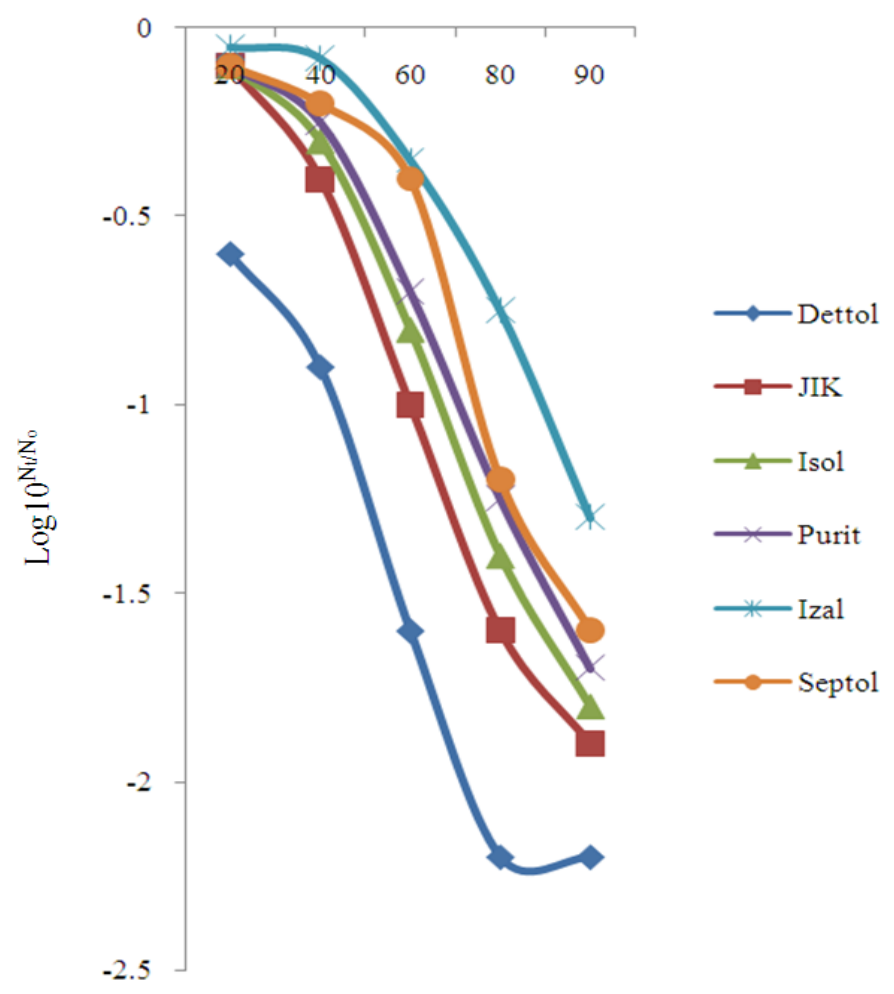

Fig. 1. Survivor curve of the effect of the various disinfectants on Staphylococcus spp. 
Onochie Charles Chimezie et al. / American Journal of Microbiology 4 (1): 9-19, 2013

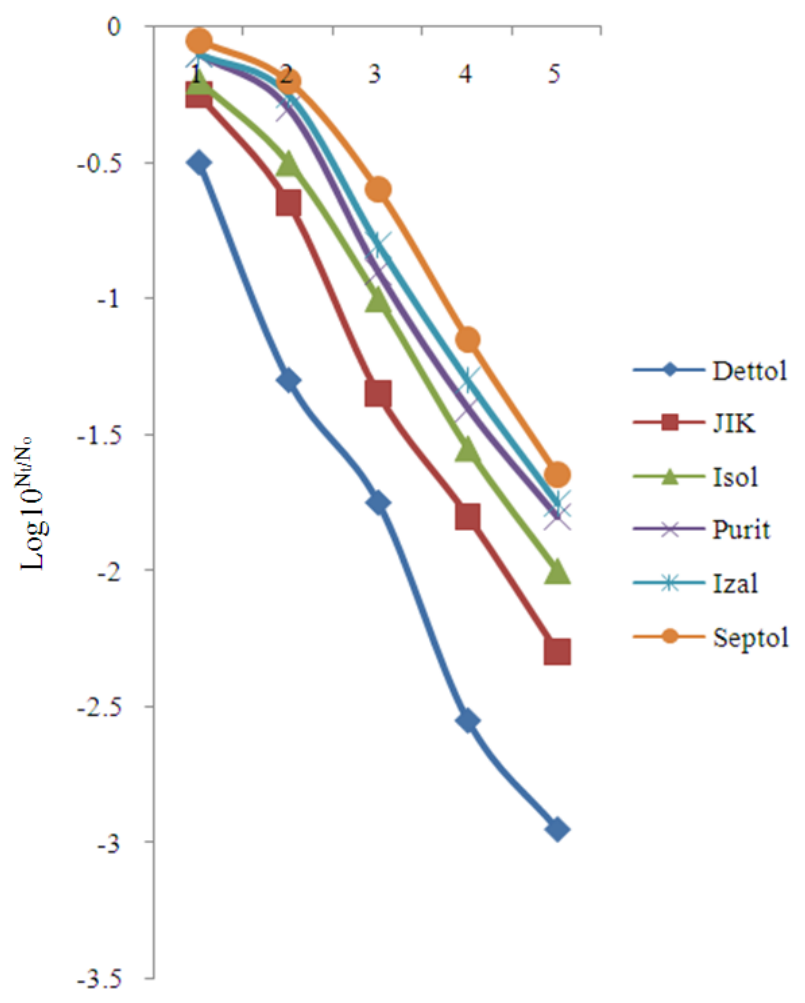

Fig. 2. Survivor curve of the effect of the various disinfectants on Bacillus spp.

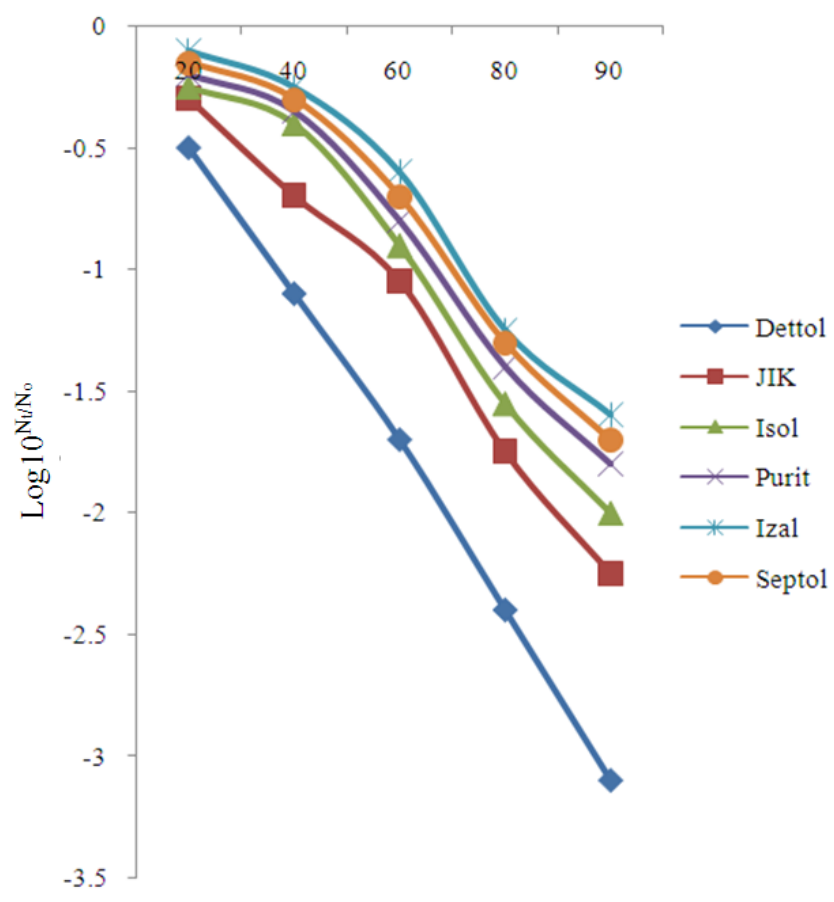

Fig. 3. Survivor curve of the effect of the various disinfectants on Escherichia spp. 
Onochie Charles Chimezie et al. / American Journal of Microbiology 4 (1): 9-19, 2013

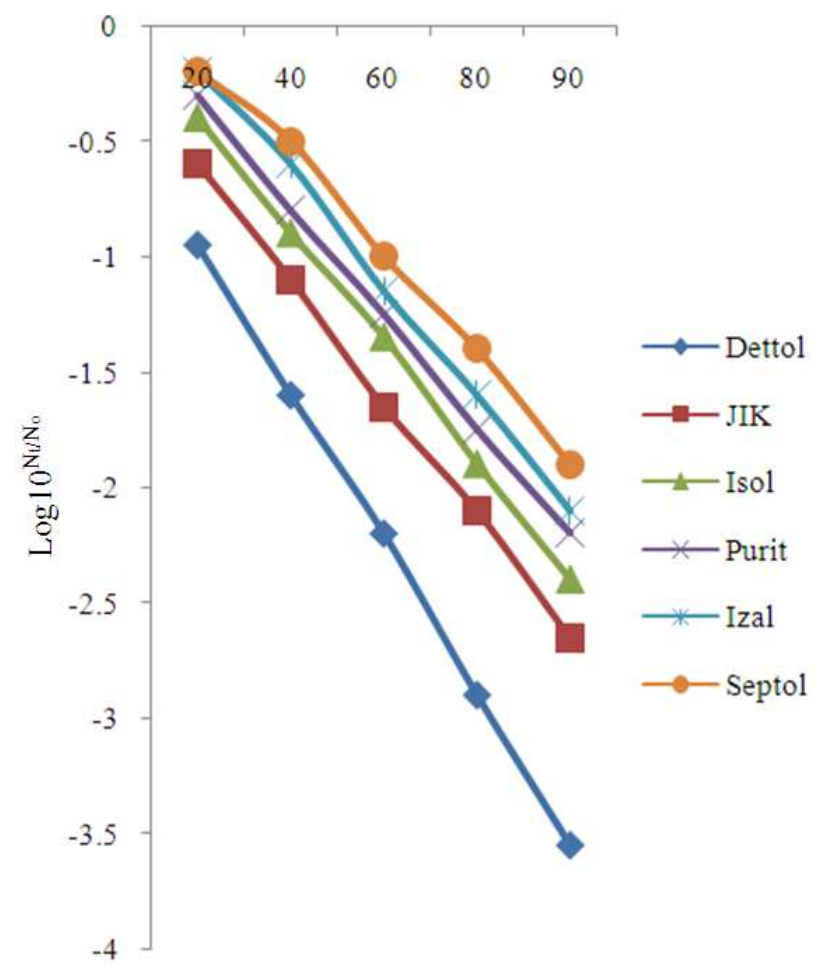

Fig. 4. Survivor curve of the effect of the various disinfectants on Pseudomonas spp.

Table 5. Killing rate $(\mathrm{K})$ of the organisms treated with the various disinfectants

\begin{tabular}{lllllll}
\hline Strain Name & Dettol $^{\circledR}$ & JIK $^{\circledR}$ & Isol $^{\circledR}$ & Purit $^{\circledR}$ & Izal $^{\circledR}$ & Septol $^{\circledR}$ \\
\hline Staphylococcus spp. & -0.044 & -0.048 & -0.052 & -0.058 & -0.086 & -0.058 \\
Bacillus spp. & -0.046 & -0.050 & -0.055 & -0.050 & -0.061 & -0.055 \\
Escherichia spp. & -0.044 & -0.055 & -0.055 & -0.055 & -0.058 & -0.058 \\
Pseudomonas spp. & -0.044 & -0.058 & -0.050 & -0.061 & -0.055 & -0.058 \\
\hline
\end{tabular}

Table 6. Slope (S) of the survivor curves of the organisms treated with the various disinfectants

\begin{tabular}{lllllll}
\hline Strain Name & Dettol $^{\circledR}$ & Isol $^{\circledR}$ & Izal $^{\circledR}$ & JIK $^{\circledR}$ & Purit $^{\circledR}$ & Septol $^{\circledR}$ \\
\hline Staphylococcus spp. & -0.033 & -0.030 & -0.028 & -0.025 & -0.017 & -0.025 \\
Bacillus spp. & -0.031 & -0.029 & -0.026 & -0.029 & -0.024 & -0.039 \\
Escherichia spp. & -0.033 & -0.026 & -0.039 & -0.026 & -0.025 & -0.025 \\
Pseudomonas spp. & -0.033 & -0.025 & -0.026 & -0.024 & -0.026 & -0.025 \\
\hline
\end{tabular}

Table 7. Decimal reduction time ( $\mathrm{min}$ ) of the organisms treated with the various disinfectants

\begin{tabular}{lllllll}
\hline Strain Name & Dettol $^{\circledR}$ & Isol $^{\circledR}$ & Izal $^{\circledR}$ & JIK $^{\circledR}$ & Purit $^{\circledR}$ & Septol $^{\circledR}$ \\
\hline Staphylococcus spp. & 30.30 & 33.33 & 35.71 & 40.00 & 58.82 & 40.00 \\
Bacillus spp. & 32.29 & 34.48 & 38.46 & 34.48 & 41.67 & 25.64 \\
Escherichia spp. & 30.30 & 38.46 & 25.64 & 38.46 & 40.00 & 40.00 \\
Pseudomonas spp. & 30.30 & 40.00 & 38.46 & 41.67 & 38.46 & 40.00 \\
\hline
\end{tabular}

\section{DISCUSSION}

Numerous studies have indicated that computer keyboards (and mouse) can become contaminated with pathogenic bacteria (Schultz et al., 2003; Hartmann et al., 2004; Rutala et al., 2006; Eltablawy and Elhifnawi, 2009; Anastasiades et al., 2009; Shen, 2010; Tagoe and Kumi-Ansah, 2011). In health care settings, it is perhaps 
not unexpected that such microorganisms would contaminate these common work surfaces. However, this present work showed that microbial contamination also occurs on computer keyboards and mouse located in a large university environment.

A total of 250 computer keyboards and mouse were examined for bacterial contamination. The bacteria isolated (Staphylococcus, Bacillus, Escherichia and Pseudomonas spp.) and their percentages of occurrence were represented in Table 1 and $\mathbf{2}$ respectively. The contamination rate of keyboards and mouse was 70.3 and $29.7 \%$, respectively. It was revealed by Hartmann et al. (2004) that the highest rate of contamination in patients, rooms was found on keyboards. Schultz et al. (2003) found that the tested 100 keyboards in 29 clinical areas for bacterial contamination, 95 from them were positive for microbial contamination. Eltablawy and Elhifnawi (2009) also showed that all the tested 24 computer keyboards and mouse at National Center for Radiation Research and Technology (NCRRT), were positive for microbial contamination. However, the degree of microbial contamination of computer keyboards and mouse is high enough to potentially allow transmission via contaminated hands (Rutala et al., 2006).

Out of 250 samples analyzed, a total of 148 bacteria isolates were obtained from computer keyboards and mouse. Out of these, $42.6 \%$ are Staphylococcus spp., $31.8 \%$ are Escherichia spp., 18.2\% are Pseudomonas spp.and $7.4 \%$ are Bacillus spp. This is in line with the study of Rutala et al. (2006) who reported that potential pathogens cultured from more than $50 \%$ of the computers included coagulase-negative Staphylococci (100\% of keyboards), diphtheroids (80\%), Micrococcus spp. (72\%) and Bacillus spp. (64\%).

Anastasiades et al. (2009) reported the presence of coagulase-negative staphylococci (68.5\%), Staphylococcus aureus (2.1\%), Gram-positive bacilli (27.1\%), Micrococcus $(0.6 \%)$ and fungi $(1.7 \%)$ on computer keyboards and mouse, indicating that Staphylococcus spp. are prevalent on computer keyboards and mouse compared to other microbial communities. The ecologic niche for $S$. aureus in humans is in the anterior nares (Miller and Diep, 2008). Onequarter to one-third of healthy persons harbour $S$. aureus in the nose at any time (Kluytmans et al., 1997) which can easily be transferred to hands by simply rubbing the nose. In this present work the highest bacterial population on computer keyboards and mouse were S. aureus (42.6\%). This strengthens the possibility of transfer of potentially pathogenic $S$. aureus through human hands which could include antibiotic resistant bacteria such as community associated Methicillin-Resistant S. Aureus (MRSA) (Miller and Diep, 2008). Inanimate objects have been known to play a role in the transmission of human pathogens either directly by surface to mouth contact or indirectly by contamination of fingers and subsequent hand to mouth contact (Rusin et al., 2002). In addition, one's palm is usually moist to a varying degree due to perspiration, which contains sodium chloride that will sustain the growth of halophilic bacteria such as $S$. aureus (Elliot et al., 1997; Mandal et al., 2004).

Shen (2010) who investigated the bacterial contamination of computer keyboards and mouse in the office reported the presence of Staphylococcus aureus, Escherichia coli and Salmonella spp. before sterilization at the following frequency 50.0, 41.7 and $8.3 \%$. Many other investigators found the presence of Escherichia spp. on computer keyboards and mouse (Man et al., 2002; Neely and Sittig, 2002; Neely et al., 2005a; Rutala et al., 2006; Kumar and Srivastava, 2012). This signifies that Escherichia spp. can also be isolated from computer keyboards and mouse at a relatively high proportion, which is in line with the result of this present work, Escherichia spp. (31.8\%).

Noskin et al. (1995) studied both computer keyboards and keyboard covers, reported their ability to harbour Vancomycin-Resistant Enterococcus faecium (VRE), Methicillin-Resistant Staphylococcus Aureus (MRSA) and Pseudomonas aeruginosa. Also Tagoe and KumiAnsah (2011) who investigated the bacterial contaminants of keyboards and mice in general offices and internet cafés, reported the presence of Pseudomonas aeruginosa. The presence of Pseudomonas aeruginosa shown by Noskin et al. (1995) and Tagoe and Kumi-Ansah (2011) is consistent with this study, showing that Pseudomonas spp. can be isolated from computer keyboards and mouse. Hence Infectious doses of this pathogen may be transferred to the mouth after handling an everyday contaminated object.

Eltablawy and Elhifnawi (2009) reported the presence of Bacillus cereus, Pseudomonas putida and Escherichia tarda, which are known to be pathogenic in nature. Das et al. (2011) reported that computer Keyboards and mouse harbour many pathogenic microorganisms, of which Bacillus species were shown to be the most predominant. Contrarily, Bacillus spp. was isolated in this study at the lowest proportion $(7.4 \%)$, but also a clear indication that computer keyboards and mouse are polymicrobial in nature. The isolation of Bacillus spp., common soil bacteria, is evidence of environmental contamination (Anderson and Palombo, 2009). 
The results obtained in this study showed that the antibacterial activities of the tested disinfectants were concentration dependent. Table 3 showed that Dettol and $\mathrm{JIK}^{\circledR}$ was the most effective in inhibiting the four bacteria at $100 \%$ concentration, followed by Isol, Izal and Purit ${ }^{\circledR}$, while Savlon ${ }^{\circledR}$ showed inhibitory activity on Staphylococcus, Bacillus and Pseudomonas spp. only, but with lower zones of inhibition than Dettol and JIK ${ }^{\circledR}$ on all the organisms tested, also Septol ${ }^{\circledR}$ showed lower zones of inhibition than Isol, Izal and Purit ${ }^{\mathbb{R}}$ on Staphylococcus and Escherichia spp..

However, at $50 \%$ concentration Dettol and $\mathrm{JIK}^{\circledR}$ were also the most effective in inhibitory activities: $12,10,13$, 10, 13, 12, 5 and 14mm on Staphylococcus, Bacillus, Escherichia and Pseudomonas spp. respectively. This was followed by Isol ${ }^{\circledR}$ with inhibition zones of 10, 11, 8 and $8 \mathrm{~mm}$ ) on the four organism tested. Izal ${ }^{\circledR}$ showed no inhibitory activity on Staphylococcus and Pseudomonas spp., but showed inhibitory activities on Bacillus and Escherichia spp. with inhibition zones of 4 and $5 \mathrm{~mm}$ respectively. In the same vein, Purit ${ }^{\circledR}$ showed inhibitory activities on Staphylococcus and Pseudomonas spp. with inhibition zones of $8 \mathrm{~mm}$ and $4 \mathrm{~mm}$ respectively, but has no inhibitory effect on Bacillus and Escherichia spp. At this $50 \%$ concentration Septol ${ }^{\circledR}$ inhibitory activities on Bacillus and Pseudomonas spp. with inhibition zones 6 and $5 \mathrm{~mm}$ respectively, but disclose no inhibitory effect on Staphylococcus and Escherichia spp. Olowe et al. (2004) reported that Dettol and Savlon $^{\circledR}$ were effective against many pathogenic organisms, especially when the number of cells present were not disinfected in the presence of excess organic matter. Hence this calls for the need for the proper removal of crumbs and spills which wind up on and between the keys that are likely to encourage the growth of microorganisms, before the commencement of disinfection practice.

However, at $12.5 \%$ concentration, Dettol and $\mathrm{JIK}^{\circledR}$ demonstrated the following zones of inhibition; 10, 8, 12, 8, 8, 5, 5 and $8 \mathrm{~mm}$ on Staphylococcus, Bacillus, Escherichia and Pseudomonas spp. respectively. Isol ${ }^{\circledR}$ showed inhibitory activity on only Staphylococcus spp. with inhibition zone of $4 \mathrm{~mm}$ and has no inhibitory effect on the other organisms. At same $25 \%$ concentration Purit, Izal and Septol ${ }^{\circledR}$ revealed no inhibitory effects on the other organisms tested. The low inhibitory activities of Septol $^{\circledR}$ on the various organisms isolated might be attributed to active ingredients contained in Septol ${ }^{\circledR}$. The resistance of microorganisms is known to be limited to only a few antimicrobial agents (Olowe et al., 2004).
Some disinfectants are reported to share the same mechanism of action with some antibiotics and this can cause resistance to disinfectants used in cleaning our environments (Heath et al., 2001). Some other studies have also suggested a potential molecular link between reduced susceptibility to some disinfectants and antibiotic resistance (Kaulfers et al., 1987). In the same vein, Iroha et al. (2011) reported that resistance of microorganisms to disinfectants within the hospital, industry and other community setting is an emerging public health concern.

The mechanism of action of disinfectant or antiseptic on the micro-organism remains the same irrespective of the type and is exerted through the penetration into the cell and action at the target site(s). The latter can produce a significant effect on the viability as most of the biocides appear to act through intra-cellular mechanism (Russell and Chopra, 1996). The sensitivity or resistance at the level of the bacterial cell membrane, therefore, can be very important factor in determining the final outcome of the treatment with the proposed disinfectant in the hospital practice. Some of these disinfectants also work by production of destructive chemicals against various pathogenic bacteria to attack membrane lipids, DNA and other essential cell components (Rutala et al., 2006).

Most antimicrobial agents show both inhibitory and lethal effects depending on the concentration used and other factors such as degree of contamination and duration of treatment. The MIC is a helpful parameter used to assess the bacteriostatic activity of a given disinfectant (Olowe et al., 2004). The MIC values of dettol, jik, isol, purit, septol and izal obtained in this study showed that concentration of the active ingredients in the recommended dilutions of the disinfectants is lethal to the organisms tested. The relationship between the MIC and the content of the disinfectant is considered to be a useful property of the agents (El-Mahmood and Doughari, 2009). Subsequently, the MIC recorded in this study further indicated that the test organisms screened were most resistant to Septol, followed by Izal and Purit ${ }^{\circledR}$ (Table 4). The high rate of decreased susceptibility to these disinfectants (Septol, Izal and Purit ${ }^{\circledR}$ ) is worrisome considering the fact that they are among the disinfectants commonly used in our environment.

Counting methods have been used to determine the number of microbial cells that survived the toxic effects of disinfectant at various time intervals for a particular period. The antimicrobial activity of the various disinfectants was assessed by performing viable cell 
counts at 20,40,60,80 and 90 min. The number of cells in organisms was observed to decrease gradually after an initial lag, the duration of which is a function of the concentration of the various disinfectants used and the type of organisms. The number of cells decreased faster in Dettol ${ }^{\circledR}$, followed by JIK $^{\circledR}$ than in Isol, Purit, Izal and Septol $^{\circledR}$ with negative slopes. When a microbial population is subjected to the toxic influence of an agent, the number of cells decreased gradually in such a manner that when the logarithm of the number of cell at any time when plotted against that time falls on a descending straight line with a negative slope (Acheampong et al., 1988). This is referred to as the logarithmic order of death (Esselen and Pflug, 1956) as shown in Table 5. On the other hand, a non-logarithmic order of death had also been reported (Reed et al., 1951; El-Bisi and Ordal, 1956). One characteristic of the logarithmic order of death is that there is a linear relationship between the logarithm of the number of survivors and time. This means that at any time interval a constant proportion of cells loose viability. All the organisms exhibited a uniform response to the various disinfectants as shown by the almost straight graphs (Fig. 1-4). This is an indication that there is no sub population of cells resistant to the various disinfectants in the test cultures. Extensive work on the mechanism of death in the presence of microbicidal concentrations of phenols and halogenated phenols (including dichloroxylenol and chlorophenol) had been documented and the mode of action of these compounds had been found to be due to their adverse effect on cellular permeability leading to inhibition of enzymes and leakage of intracellular materials out of the cell (Allwood and Hugo, 1971; Hugo and Bloomfield, 1971). Thus, the cytoplasmic membrane and its component are considered to be the main site of action of the disinfectants used in the presence of lag especially in the higher use-dilutions of this study. The lag is more pronounced when Dettol ${ }^{\circledR}$ was used than other disinfectants in this study. The presence of the lag in microbicidal concentrations of toxic agents have been attributed to non uniform distribution of the cells in the suspension as single cells, but were rather grouped as clumps (Meynell and Meynell, 1970; Cove and Holland, 1983).

However, results of this study revealed low values of the lag where high concentration of Dettol and JIK ${ }^{\circledR}$ used the treatment of the organisms. Variations in use dilutions of the disinfectants affected the kinetics of cell death with respect to the length of the lag, the DRT (Table 7) and the slope of the graphs (6). The relationship between the concentration of the various disinfectants used and the above parameters are measures of resistance of cells to the disinfectants. For complete killing of the cells, a sufficiently high concentration of a disinfectant molecule must be in contact with the organisms for a time greater than the lag prior to exponential order of death (Cove and Holland, 1983).

The Decimal Reduction Time (DRT), is the time required for a disinfectant at a certain temperature or concentration to kill $90 \%$ of the organisms being studied (Mazzola et al., 2003). The DRT was calculated from slopes of the curves (Table 7). The DRT depended on the concentration of the disinfectant and also on the type and resistance of the microorganism used. Thus in this study, the test organisms were more resistant to the activity of Septol and Izal $^{\circledR}$ than Dettol, JIK, Isol and Purit $^{\circledR}$. The order of the decreasing activities of the disinfectants on the test organisms: Dettol> JIK $>$ Isol $>$ Purit $>$ Izal $>$ Septol ${ }^{\circledR}$.

\section{CONCLUSION}

In this study, it was found that there was a higher contamination rate of computer keyboards and mouse. The use of Dettol ${ }^{\circledR}$ for the routine disinfection of computer keyboards and mouse is hereby highly suggested.

On the basis of these findings, it is suggested that routine cleaning of keyboards and mouse may aid the fight against pathogens in various communities. Also, hand washing before and after contact with keyboards and mouse should significantly reduce the risk of contamination and cross transmission.

\section{REFERENCES}

Acheampong, Y.B., A. El-Mahmood and P.F. Olurinola, 1988. The antibacterial properties of the liquid antiseptic TCP. Ind. J. Pharm. Sci., 50: 183-186.

Allwood, M.C. and W.B. Hugo, 1971. The Leakage of Cations and Amino Acids from Staphylococcus aureus exposed to moist heat, phenol and dinitrophenol. J. Applied Microbiol., 34: 368-375. DOI: 10.1111/j.1365-2672.1971.tb02296.x

Anastasiades, P., T.L. Pratt, L.H. Rousseau, W.J. Steinberg and G. Joubert, 2009. Staphylococcus aureus on computer mice and keyboards in intensive care units of the Universitas Academic Hospital, Bloemfontein and ICU staff's knowledge of its hazards and cleaning practices. South Afr. J. Epidemiol. Infect., 24: 22-26. 
Anderson, G. and E.A. Palombo, 2009. Microbial contamination of computer keyboards in a university setting. Am. J. Infect. Control, 37: 507-509. DOI: 10.1016/j.ajic.2008.10.032

Awodele, O., P.M. Emeka, H.C. Agbamuche and A. Akintonwa, 2007. The antimicrobial activities of some commonly used disinfectants on Bacillus subtilis, Pseudomonas aeruginosa and Candida albicans. Afr. J. Biotech., 6: 987-990.

Cheesbrough, M., 2006. District Laboratory Practice in Tropical Countries. 2nd Edn., Cambridge University Press, Cambridge, ISBN-10: 113944929X, pp: 440.

Cove, J.H. and K.T. Holland, 1983. The effect of benzoyl peroxide on cutaneous micro-organisms in vitro. J. Applied Bacteriol., 54: 379-382. DOI: 10.1111/j.1365-2672.1983.tb02631.x

Das, A., R. Kansal, A.K. Asthana, A. Pandey and M. Madan, 2011. E-Fomites. Annals Biol. Res., 2: 111115.

Eguia, J.M. and H.F. Chambers, 2003. Communityacquired methicillin-resistant Staphylococcus aureus: Epidemiology and potential virulence factors. Curr. Infect. Dis. Rep., 5: 459-466. DOI: 10.1007/s11908-003-0087-6

El-Bisi, H.M. and Z.S. Ordal, 1956. The effect of certain sporulation conditions on the death rates of Bacillus coagulans var thermocidurans. J. Bacteriol., 71: 1-7. PMID: 13286224

Elliot, T., M. Hastings and U. Desselberger, 1997. Lecture Notes on Medical Microbiology. 3rd Edn., Wiley-Blackwell, ISBN-10: 0632024461, pp: 352.

El-Mahmood, A.M. and J.H. Doughari, 2009. Bacteriological examination of some diluted disinfectants routinely used in the Specialist Hospital Yola, Nigeria. Afr. J. Pharmacy Pharmacol., 3: 185-1909.

Eltablawy, S.Y. and H.N. Elhifnawi, 2009. Microbial contamination of some computer keyboards and mice in National Center for Radiation Research and Technology (NCRRT). World Applied Sci. J., 6: 162-167.

Esselen, W.B. and I.J. Pflug, 1956. Thermal resistance of putrefactive anaerobe no. 3679 spores in vegetables in the tempetature range of $250-290^{\circ} \mathrm{F}$. Food Technol., 10: 557-560.

Hartmann, B., M. Benson, A. Junger, L. Quinzio and R. Rohrig et al., 2004. Computer keyboard and mouse as a reservoir of pathogens in an intensive care unit. J. Clin. Monit., 18: 7-12. DOI: 10.1023/B:JOCM.0000025279.27084.39
Heath, R.J., S.W. White and C.O. Rock, 2001. Lipid biosynthesis as a target for antibacterial agents. Prog. Lipid. Res., 40: 467-497. DOI: 10.1016/S0163-7827(01)00012-1

Hugo, W.A. and S.F. Bloomfield, 1971. Studies on the mode of action of phenolic antibacterial agent fenticlor against Staphylococcus aureus and Escherichia coli 1. Adsorption of fenticlor by the bacterial cell and its antibacterial activity. J. Applied Bacteriol., 34: 557-567. DOI: 10.1111/j.13652672.1971.tb02318.x

Iroha, I.R., A.E. Oji, O.K., Nwosu and E.S. Amadi, 2011. Antimicrobial activity of Savlon ${ }^{\circledR}$, Izal ${ }^{\circledR}$ and Z-germicide ${ }^{\circledR}$ against clinical isolates of Pseudomonas aeruginosa from hospital wards. Eur. J. Dent. Med., 3: 32-35. DOI: 10.3923/ejdm.2011.32.35

Kaulfers, P.M., H. Karch and R. Laufs, 1987. Plasmidmediated formaldehyde resistance in Serratia marcescens and Escherichia coli: Alterations in the cell surface. Zentralbl. Bakteriol. Mikrobiol. Hyg. A., 226: 239-248. PMID: 3321766

Kluytmans, J., A. Van-Belkum and H. Verbrugh, 1997. Nasal carriage of Staphylococcus aureus: Epidemiology, underlying mechanisms and associated risks. Clin. Microbiol. Rev., 10: 505-550. PMID: 9227864

Kumar, A. and M. Srivastava, 2012. Computer components in college and its surroundings encompass the pathogenic bacteria. J. Applied Sci. Environ. Sanit., 7: 43-47.

Man, G.S., M. Olapoju and M.V. Chadwick, 2002. Bacterial contamination of ward-based computer terminals. J. Hosp. Infect., 52: 314-318. DOI: 10.1053/jhin.2002.1302

Mandal, B.K., E.G.L. Wilkins, E.M. Dunbar and R. Mayon-White, 2004. Lecture Notes: Infectious Diseases. 6th Edn., Wiley, Oxford, ISBN-10: 1405108207, pp: 280.

Mazzola, P.G., T.C.V. Penna and A.M. Martins, 2003. Determination of decimal reduction time (D-value) of chemical agents used in hospitals for disinfection purposes. BMC Infect. Dis., 3: 131-140. DOI: 10.1186/1471-2334-3-24

Meynell, G.G. and E. Meynell, 1970. Theory and Practice in Experimental Bacteriology. 2nd Edn., CUP Archive, ISBN-10: 052107682X, pp: 346.

Miller, L.G. and B.A. Diep, 2008. Colonization, fomites and virulence: Rethinking the pathogenesis of community-associated methicillin-resistant Staphylococcus aureus infection. Clin. Infect. Dis., 465: 752-760. DOI: $10.1086 / 526773$ 
Neely, A.N. and D.F. Sittig, 2002. Basic microbiologic and infection control information to reduce the potential transmission of pathogens to patients via computer hardware. J. Am. Med. Inform. Assoc., 9: 500-508. DOI: 10.1197/jamia.M1082

Neely, A.N., I.A. Holder, J.P. Wiener-Kromsh and T. Sawa, 2005a. Passive anti-per $\mathrm{V}$ treatment protects burned mice against Pseudomonas aeruginosa challenge. Burns, 31: 153-158. DOI: 10.1016/j.burns.2004.09.002

Neely, A.N., J.M. Weber, P. Daviau, A. MacGregor and C. Miranda et al., 2005b. Computer equipment used in patient care within a multihospital system: Recommendations for cleaning and disinfection. Am. J. Infect. Control, 33: 233-237. PMID: 15877019

Noskin, G.A., V. Stosor, P. Bednarz and T. Suriano, 1995. Recovery of vancomycin-resistant Enterococci on fingertips and environmental surfaces. Infect. Control Hosp. Epidemiol., 16: 577581. DOI: $10.1086 / 647011$

Olowe, O.A., A.B. Olayemi, K.I.T. Eniola and A.O. Adeyeba, 2004. Anti bacterial activity of some selected disinfectants regularly used in hospitals. Afr. J. Clin. Exp. Microbiol., 5: 126-130.

Pancholi, P., M. Healy, T. Bittner, R. Webb and F. $\mathrm{Wu}$ et al., 2005. Molecular characterization of hand flora and environmental isolates in a community setting. J. Clin. Microbiol., 43: 52025207. DOI: 10.1128/JCM.43.10.5202-5207.2005

Ravichandran, D., 2001. Introduction to Computers and Communication. 1st Edn., Tata McGraw-Hill Education, New Delhi, ISBN-10: 0070435650. pp: 584.

Reed, J.M., C.W. Bohrer and E.J. Cameron, 1951. Spore destruction rate studies on organisms of significance in the processing of canned foods. Food Res., 16: 383-408. DOI: 10.1111/j.1365-2621.1951.tb17396.x

Rusin, P., S. Maxwell and C. Gerba, 2002. Comparative surface-to-hand and fingertip-to-mouth transfer efficiency of gram-positive bacteria, gramnegative bacteria and phage. J. Applied Microbiol., 93: 585592. DOI: 10.1046/j.1365-2672.2002.01734.x
Russell, A.D. and I. Chopra, 1996. Understanding Antibacterial Action and Resistance. 2nd Edn., Ellis Horwood, Hemel Hempstead, ISBN-10: 0131248278, pp: 292.

Rutala, W.A., M.S. White, M.F. Gergen and D.J. Weber, 2006. Bacterial contamination of keyboards: Efficacy and functional impact of disinfectants. Infect. Control Hosp. Epidemiol., 27: 372-377. DOI: 10.1086/503340

Schultz, M., J. Gill, S. Zubairi, R. Huber and F. Gordin, 2003. Bacterial contamination of computer keyboards in a teaching hospital. Infect. Control Hosp. Epidemiol., 24: 302-313. DOI: $10.1086 / 502200$

Shen, X., 2010. Investigation of the bacterial contamination of computer keyboard and mouse in the office. J. Environ. Occupat. Med.

Siegmund, K., N. Hubner, C.D. Heidecke, R. Brandenburg and K. Rackow et al., 2010. Are laptop ventilation-blowers a potential source of nosocomial infections for patients? GMS Krankenhaushyg Interdiszip, 5: 7-7. DOI: 10.3205/dgkh000150

Stepanovic, S., I. Cirkovic, S. Djukic, D. Vukovic and M. Svabic-Vlahovic, 2008. Public transport as a reservoir of methicillin-resistant staphylococci. Lett. Applied Microbiol., 47: 339-341. DOI: 10.1111/j.1472-765X.2008.02436.x

Tagoe, D.N.A. and F. Kumi-Ansah, 2011. Computer keyboard and mice: Potential sources of disease transmission and infections. Internet J. Public Health.

Wilson, A.P., S. Hayman, P. Folan, P.T. Ostro and A. Birkett et al., 2006. Computer keyboards and the spread of MRSA. J. Hosp. Infect., 62: 390-402. DOI: 10.1016/j.jhin.2005.09.007 